\title{
The Sound of Silence: An Epistle on Prayer and the Constitution*
}

\author{
Walter Dellinger†
}

July 30,1986

Members of the United States Senate

United States Capitol

Washington, D.C. 20510

Dear Senator:

A Report of the Committee on the Judiciary of the United States Senate $^{1}$ has just crossed my desk. From it I learn that the Committee has, by a substantial majority vote, ${ }^{2}$ favorably reported to the full Senate a bill proposing a "Voluntary Silent Prayer Amendment" to the Constitution of the United States. I write to urge you to reject this and similar amendments as they come before you in the future. This particular proposal is, at one and the same time, both trivial and dangerous. In terms of its ostensible objective-to permit a silent time to be set aside during which pupils may choose to engage in silent prayer-it is simply unnecessary. There is no present constitutional barrier to the creation by school boards of such a moment of silence. Its less visible but far more profound effect, however, may be to permit public officials at every level of government to promote a religious exercise and to influence, encourage, and persuade children to engage in a religious activity. This seemingly innocuous amendment, if proposed by Congress and ratified by the states, would thus have consequences significantly more damaging to religious liberty than has yet been acknowledged.

* This essay is offered in honor of Charles L. Black, Jr., who has more than once intervened in the affairs of state with timely letters on behalf of enduring constitutional values. See Black, Amending the Constitution: A Letter to a Congressman, 82 Y ALE L.J. 189 (1972); Black, The Marital and Physician Privileges-A Reprint of a Letter to a Congressman, 1975 DukE L.J. 45; Black, On Article I, Section 7, Clause 3-and the Amendment of the Constitution, 87 YALE L.J. 896 (1978); Black, Amendment by National Constitutional Convention: A Letter to a Senator, 32 OkLA. L. REv. 626 (1979).

$\dagger$ Professor of Law, Duke University.

1. Senate Comm. on Judiciary, Voluntary Silent Prayer Constrtutional AmendMENT, S. Rf.p. No. 165, 99th Cong., 1st Sess. (1985) [hercinafter cited as Senste Report].

2. On October 3,1985, the full Committee on the Judiciary favorably reported S.J. Res. 2, 99th Cong., ist Sess. (1985), by a vote of 12 to 6 . Senate Report, supra note 1 , at 27. 
I.

The proposed amendment reads as follows:

\begin{abstract}
Article -
Nothing in this Constitution shall be construed to prohibit individual or group silent prayer or reflection in public schools. Neither the United States nor any State shall require any person to participate in such prayer or reflection, nor shall they encourage any particular form of silent prayer or reflection. ${ }^{3}$
\end{abstract}

An initial reading of the text of this proposed constitutional amendment suggests that its effect would be quite minimal. Unlike an earlier amendment proposed by President Reagan, ${ }^{4}$ which would have permitted government-sponsored, teacher-led group recital of spoken prayer, this amendment would avoid the spectre of involving bureaucrats and politicians in the composition or selection of prayers. This apparently more modest Silent Prayer Amendment seems merely to remove some existing constitutional barrier that precludes school children from engaging in a school-organized moment of silence in which those who wish to pray silently may do so.

If this were the only effect of this amendment, then it would address a non-problem. The notion (repeatedly implied but never explicitly stated in the Senate Report) that Supreme Court decisions forbid schools from organizing moments of silence is highly dubious at best. If there is no such existing barrier, then the affirmative case for the amendment virtually collapses.

Nothing in the Supreme Court's 1962 decision in Engle v. Vitale precludes a school system from establishing a moment of silence. In Engle, the Court considered a prayer that the defendant school board, acting in its official capacity under state law, required every principal to cause to be said aloud by each class at the beginning of each school day. The prayer had been composed by a group of politically-appointed state officials, the Board of Regents. Justice Black, writing for the Court, properly focused

3. SENATE REPORT, supra note 1, at 1-2.

4. The President's proposed amendment read: "Nothing in this Constitution shall be construed to prohibit individual or group prayer in public schools or other public institutions. No person shall be required by the United States or any State to participate in prayer." Message to the Congress Transmitting Proposed Legislation, 18 WeEkly CoMP. Pres. Doc. 665 (1982). For comments on the effect of this proposal, see Proposed Constitutional Amendment to Permit Voluntary Prayer, Hearings on S.J. Res. 199 Before the Senate Comm. on the Judiciary, 97th Cong., 2nd Sess. (1982) [hereinafter cited as 1982 Hearings], and Voluntary School Prayer Constitutional Amendment, Hearings on S.J. Res. 73 and S.J. Res. 212 Before the Subcomm. on the Constitution of the Senate Comm. on the Judiciary, 98th Cong., 1st Sess. (1983) [hereinafter cited as 1983 Hearings].

5. 370 U.S. 421 (1962). 
upon the state's selection and promotion of the prayer and asserted that "it is no part of the business of government to compose official prayers for any group of the American people to recite as a part of a religious program carried on by government."

There was no indication in the Court's subsequent decisions concerning religious activity in the public schools that it is constitutionally impermissible for pupils themselves to choose to pray. ${ }^{7}$ In the two decades since Engle many legal scholars-including Paul Kauper, Jefferson Fordham, Paul Freund, Jesse Choper, and Laurence Tribe-have expressed the opinion that school officials themselves could, without constitutional infirmity, provide an organized moment of silence in which students might choose to pray silently. ${ }^{8}$

When the constitutional amendment proposed by President Reagan was first brought before the Senate Judiciary Committee, several witnesses, including Geoffrey Stone, Terrance Sandalow and Norman Redlich, suggested that at least some form of a moment of silence would most likely be sustained by the Court; 9 this would permit an opportunity for prayer in school (though in a form substantially different from the organized group oral prayer then being proposed by the President).

The substitute Silent Prayer Amendment now before you was later brought forward. In subsequent hearings, I argued that such an amendment was unnecessary since "a policy that said that there will be a moment of reflective silence observed at the beginning of each school day, would clearly pass constitutional muster."10 Even though I erroneously thought that the Supreme Court might in fact sustain even those silence

6. Id. at 425 .

7. Id. School Dist. of Abington Township v. Schempp, 374 U.S. 203 (1963), was but a step away from Engle. The religious exercises at issue in Schempp were not composed, but rather chosen by, government officials: The state legislature required daily readings in every school from the Holy Bible; the school district added the requirement that each class recite the Lord's Prayer in unison.

8. See Kauper, Prayer, Public Schools and the Supreme Court, 61 Mich. L. REv. 1031, 1041 (1963); Fordham, The Implications of the Supreme Court Decisions Dealing with Religious Practices in the Public Schools, $6 \mathrm{~J}$. Church \& STATE 44, 55-56 (1964); Freund, The Legal Issue, in P. Freund \& R. Ulitch, Religion and THE Public Schools 23 (1965); Choper, Religion in the Public Schools: A Proposed Constitutional Standard, 47 MINN. L. REv. 329, 371 (1963); L. TRIBE, AMERICAN ConstTtutional. Law \& 14-6, at 829 (1978).

9. See Stone, In Opposition to the School Prayer Amendment, 50 U. CHI. L. Rev. 823, 844 (1983) ("It is generally accepted, for example, that a public school may set aside a minute at the beginning of the school day for 'silent meditation or prayer' without running afoul of the establishment clause."); 1982 Hearings, supra note 4, at 381 (testimony of Terrance Sandalow) (decisions sustaining moments of silence are "undoubtedly consistent with the Supreme Court's decisions in Engle and Schempp"); id. at 395 (testimony of Norman Redlich) ("there is a reasonably good chance that [a period of silent meditation or prayer] would be sustained").

10. 1983 Hearings, supra note 4, at 369 (testimony of the author). Paul Bender also expressed the view that "[i]f [the amendment] means to authorize a moment of silence during which the children may, if they wish, pray or meditate in other ways, then ... I think it is unnecessary to amend the Constitution to achieve that result." Id. at 381 . 
statutes that mentioned prayer, I argued that such a statutory mention of prayer was constitutionally dubious, stating that:

If you add the word "prayer" [to the state statute], or specifically suggest prayer in the school board policy, as one of the alternatives, and if one is litmus paper-sensitive to establishment violations, I think you would have to find there a trace element of establishmentism, if the Government is specifically suggesting that one of the things you might do with your time is utilize it for prayer. ${ }^{11}$

Not long after the Senate Hearings, the Supreme Court decided Wallace v. Jaffree. ${ }^{12}$ Because a majority of the Court appeared to provide a clear and positive answer to the question of whether a neutral moment-ofsilence statute would be held constitutional, ${ }^{13} \mathrm{I}$ assumed that the Silent Prayer Amendment to the Constitution would no longer be pursued. I was surprised to learn that the Judiciary Committee had nonetheless approved the Silent Prayer Amendment, and I was astonished to read in the Committee Report the statement that "[i]t is the view of the Committee that the Jaffree decision effectively prohibits silent prayer in public schools."14 A review of Jaffree demonstrates that this last statement is flatly wrong. Three separate Alabama statutes were originally challenged in Wallace v. Jaffree. One provided that teachers could lead all "willing students" in group oral recital of a specified prayer that was set out in the statute. The Supreme Court summarily upheld the invalidation of this statute, thus unanimously reaffirming its original school prayer decision. A second Alabama statute, adopted in 1978, authorized a one-minute period for silent meditation in all public schools. The district court upheld this statute, and the plaintiffs did not challenge it on appeal. The third Alabama statute, adopted in 1981, differed from the preexisting moment-of-silence statute in that it added the words "or voluntary prayer." It was this statute that the Court considered and invalidated in Jaffree. ${ }^{15}$

Justice Stevens noted in his Opinion of the Court that the unchallenged 1978 statute fully accomplished the goal of setting aside a moment of silence in which students who chose to pray could do so. Thus the only thing the 1981 silent prayer statute at issue in Jaffree added to the earlier moment of silence law was "the State's endorsement and promotion of

11. Id. at $369-70$.

12. 105 S. Ct. 2479 (1985).

13. Id. at 2491 . I am using the phrases "neutral moment of silence" and "pure moment of silence" to refer to those statutes that simply establish a silent moment without specifying that the moment is "for prayer" or "for prayer or contemplation" of "for prayer or meditations."

14. Senate RePort, supra note 1 , at 36 .

15. This statutory history is discussed in Jaffree, $105 \mathrm{~S}$. Ct. at 2481-82. 
religion and a particular religious practice."16 Justice Stevens' opinion, joined by Justices Brennan, Marshall, Blackmun, and Powell, suggests that it is a permissible purpose for a state to adopt legislation "protecting every student's right to engage in voluntary prayer during an appropriate moment of silence during the school day"17 - a right that the Court said was protected by the earlier, neutral moment-of-silence statute. Such a purpose was, in the Court's view, "quite different from" the "legislative intent to return prayer to the public schools."18 The thrust of Justice Stevens' opinion for the Court-that the flaw in the statute before the Court was the state's explicit endorsement of "prayer" as an officially approved use of a moment of silence-appears to be fully consistent with the idea that a statute like Alabama's earlier, neutral "moment of silence" law is constitutionally permissible.

The implication that the Court would sustain the adoption by states of neutral moment-of-silence statutes becomes even clearer upon reading the concurring and dissenting opinions in Jaffree. Although "head-counting" of Justices is generally a poor way to think about constitutional issues, it is certainly worth doing before one proposes what might be an unnecessary constitutional amendment. Three members of the Court, Chief Justice Burger and Justices Rehnquist and White, dissented in Jaffree and would have upheld even the Alabama statute that explicitly specified prayer. ${ }^{18}$ Justice O'Connor, concurring, stated that moment-of-silence statutes that did not expressly promote prayer would be constitutional, noting that scholars have "suggested that a moment of silence in public schools would be constitutional. As a general matter, I agree."20 Justice Powell, concurring, stated that "I agree fully with Justice O'Connor's assertion that some moment-of-silence statutes may be constitutional, a suggestion set forth in the Court's opinion as well."21 Five members of the Court have thus stated clearly that they would sustain moment of silence laws that did not involve legislative promotion of religion by singling out prayer as one of the officially preferred activities. They might well be joined by all the other members of the Court to make that result unanimous.

I would not suggest that Congress set aside its proposed constitutional amendment in reliance on a parsing of the opinions in Jaffree were I not also convinced that the Court's apparent resolution of this prob-

16. Id. at 2491 n. 45 .

17. Id. at 2491 .

18. Id.

19. Id. at 2505 (Burger, C.J., dissenting); id. at 2508 (White, J., dissenting); id. (Rehnquist, J., dissenting).

20. Id. at 2499 (O'Connor, J., concurring) (citations omitted).

21. Id. at 2493 (Powell, J., concurring). 
lem-sustaining laws that simply create an undesignated, neutral moment of silence, while invalidating those that involve governmental promotion or endorsement of "prayer"-is fundamentally sound and therefore likely to become stable constitutional doctrine. As I will attempt to show, neutral moments of silence can withstand criticism both from those who believe that all moment-of-silence statutes (including those specifically designating prayer) should be sustained, and from those who would argue that all silence laws (including those that are facially neutral) should be held unconstitutional.

Jaffree's invalidation of a silence law "merely" because it added to preexisting law the words "or voluntary prayer" has been criticized by those who would have sustained it as unduly fastidious. Justice White, dissenting, read the Alabama legislature's addition of the word "prayer" not as a state suggestion or endorsement of prayer, but rather as an informational device that merely let students know that prayer is one acceptable activity. So read, White suggests, the statute should no more be unconstitutional than would be a teacher answering in the affirmative if a student were to ask if it is permissible to pray during a moment of silence. ${ }^{22}$

The notion that explicit designation of "prayer" in a state statute does not constitute state endorsement or encouragement seems disingenuous. Imagine a state statute providing that a moment of silence be conducted at the beginning of each school day for "meditation or erotic fantasy." Could one plausibly say in that case that the state is being wholly "neutral" with regard to "erotic fantasy," that the statute merely reflects the fact that students can (and some no doubt will) use any period of silence for that purpose? In my view, the seemingly trivial fact of the addition of the word "prayer" crosses the line of constitutionality precisely because it is utterly unnecessary to the goal of creating a formal opportunity for reflection in which students can, if they wish, choose to pray. That purpose is wholly accomplished by a statute or policy that simply provides that a moment of silence be set aside. If a simple moment of silence is created, parents, priests, rabbis, and ministers can, if they wish, suggest to their children or parishioners that they use the moment of silence for prayer. Providing in the state's Code of Laws that "prayer" is a designated activity takes the state itself across a thin line and into the improper business of official endorsement of a religious exercise.

The other apparent conclusion of Jaffree-that moment-of-silence statutes not specifically mentioning prayer are constitutionally permissible-is somewhat more problematic. As I continue to reflect on this problem, I

22. Id. at 2508 (White, J., dissenting). 
become less certain that such laws should be upheld, ${ }^{23}$ (even though I remain convinced that the Supreme Court will in fact sustain such statutes). Silence can be a powerful message. Since a normal school day ordinarily includes any number of occasions during which an individual student acting on her own initiative can engage in a moment of silent prayer or reflection, the formal creation in public school classrooms of an organized, teacher-supervised moment of silence is an event that has no readily apparent purpose-unless the government is attempting to convey a message. ${ }^{24}$ Even where no textual mention is made of prayer, a community of observers may well perceive that the "meaning" of a school-organized moment of silence is that the government is endorsing something, and that something might be seen as religion. As Dean Redlich notes, "[a]ll prescribed moments of silence are highly suspect."2s

There remains, nonetheless, a substantial basis for the Court's conclusion that "pure" moment-of-silence statutes should be sustained. Commentators who have found such statutes invalid ${ }^{28}$ have generally done so for reasons that seem to me to be unpersuasive. Some have found that neutral moment-of-silence statutes fail to be supported by a "secular purpose"-the first requirement of what is awkwardly known as the "threepronged Lemon test" used by the Court in establishment clause cases. ${ }^{27}$. The district court that decided May $v$. Cooperman, ${ }^{28}$ for example, first found that the alleged secular purposes of a silence statute-such as pro-

23. Compare my testimony in the 1983 Hearings, supra note $4,369-70$.

24. For thoughtful discussions of these issues, see Gedicks, Motivation, Rationality, and Secular Purpose in Establishment Clause Review, 1985 ARIZ. ST. L.J. 677, 720-721, and Marshall, "We Know It When We See It:" The Supreme Court and Establishment, 59 S. CAL. L. REv. 495, 541-44 (1986).

25. Redlich, Separation of Church and State: The Burger Court's Tortuous Journey, 60 Notre DAmE: L. Rrv. 1094, 1136 (1985). Dean Redlich nonetheless agrees that "one can conclude that a 'pure' moment of silence law is probably valid unless the legislative history dilutes the purity." Id. at 1135 (citation omitted).

26. See, e.g., Note, The Unconstitutionality of State Statutes Authorizing Moments of Silence in the Public Schools, 96 Harv. L. Rev. 1874 (1983); Note, Daily Moments of Silence in Public Schools: A Constitutional Analysis, 58 N.Y.U. L. REv. 364 (1983) [hereinafter cited as Note, Daily Moments of Silence].

27. The "test" was first fashioned into a formula in Lemon v. Kurtzman, 403 U.S. 602, 612-13 (1971). There, the Court attempted to reduce its rich jurisprudence of religion into a three-part formula. To "pass muster" under the establishment clause: "First, the statute must have a secular legislative purpose; second, its principle or primary effect must be one that neither advances nor inhibits religion; finally, the statute must not foster 'an excessive government entanglement with religion." Id. (citations omitted).

Like most such formulae, the "three-pronged Lemon test" tends to give a misleading impression that some fixed mechanism can lead to consistent and predictable results. This test is an example of the unfortunate "formulaic style" of opinion-writing that the Supreme Court has been given to in recent years. As Charles Black, Jr. has written: "Some people seem to think such general formulae should be essayed as often as possible; I think they should be constructed as rarely as possible." C. Bi.Ac:k, Decision According to LAw 61-62 (1981). See also Nagel, The Formulaic Constitution, 84 Mic:H. L. REv. 165 (1985).

28. 572 F. Supp. 1561 (D.N.J. 1983). 
viding a transition to the school day or a means for settling children down-were "pretextual," post-hoc rationalizations. Since no legitimate "secular purpose" was found for the statute, it was held invalid. ${ }^{29}$

The problem with this analysis is the initial assumption that a literal "secular purpose" is required. The "secular purpose" part of the Lemon formula is a somewhat inaccurate reformulation of the sensible principle drawn from earlier cases that if the purpose of an enactment is the advancement (or inhibition) of religion, it violates the Establishment Clause. ${ }^{30}$ The encapsulation of this principle as the "secular purpose prong" does not quite capture the original meaning: The absence of a secular purpose is not co-extensive with the presence of a forbidden purpose of advancing religion. The creation of a moment of reflective silence may be a case falling precisely into this gap. A statute that provides an occasion in which those who freely choose to do so may pray cannot candidly be described as having a "secular" purpose; this, however, does not mean that the legislative purpose is necessarily to "advance religion," nor (to use Justice O'Connor's promising approach) does such a neutral moment invariably constitute a legislative "endorsement" of religion. ${ }^{31}$

A neutral moment of silence is a brief "open forum" functionally similar to the student activity period whose use for religious purposes by voluntary groups of university students was upheld by the Supreme Court in Widmar $v$. Vincent. ${ }^{32}$ By requiring equal access by student-organized religious groups to university facilities, the Widmar decision necessarily rejects the proposition that the Constitution precludes prayer or religious activity from occurring in public buildings or on other state property. Those who would invalidate a neutral moment-of-silence law on the basis that such a statute is a "subterfuge' for restoring prayer to the classroom"3s thus overlook the fact that there is nothing constitutionally offensive about the mere existence of prayer in the public schools or anywhere else. ${ }^{34}$ The constitutional evil to be avoided is government encouragement

29. Id. at 1572. A panel of the Court of Appeals for the Third Circuit affirmed, even though its decision came after the Supreme Court's decision in Jaffree, and even though it concluded that there was no legislative intention to encourage prayer over other alternatives. May v. Cooperman, 780 F.2d 240, 252-53 (3d Cir. 1985).

30. The transition may have first occurred in a passing phrase in School Dist. of Abington Township v. Schempp, 374 U.S. 203, 222 (1963), where Justice Clark equated the "advancement of religion" with the absence of "a secular legislative purpose."

31. Wallace v. Jaffree, 105 S. Ct. 2479, 2497 (1985) (O'Connor, J., concurring). I think that the correct approach was most nearly captured by John Hart Ely in 1970 when he wrote that judicial intervention is warranted whenever there is proof that a government decision "resulted from a desire comparatively to favor or disfavor a religion or religion generally." Ely, Legislative and Administrative Motivation in Constitutional Law, 79 YALE L.J. 1205, 1314 (1970).

32. 454 U.S. 263 (1981).

33. See Note, Daily Moments of Silence, supra note 26, at 371 (citations omitted).

34. For a thoughtful discussion of the open forum concept, see Loewy, School Prayer, Neutrality, and the Open Forum: Why We Don't Need a Constitutional Amendment, 61 N.C.L. REv. 141 
or inducement to pray or not to pray. As long as prayer results from the private choice of individual citizens, the Constitution is not violated. ${ }^{36}$

The fact that some legislators may hope (or even "hope and pray") that children will choose to use an undesignated moment of reflective silence for prayer should not in itself be sufficient to invalidate such a statute. It is often the case that one who helps create an open, "neutral" forum has some hope or expectation about how that forum will be used. A Republican city councilman may vote to create a "first come, first served" speaker's box in the public park in the hope that most speakers will choose to argue persuasively the case for the virtues of the Republican Party, while a Democratic colleague may support the ordinance with exactly the opposite hope or expectation. The key factor, for neutrality analysis, is the dispositive role of private citizen choice. If the government has scrupulously refrained from tilting the forum for or against religion or Republicans or Democrats, but has provided an occasion for wholly free choice by the speaker (or in our case, the meditator), uninfluenced by any governmental endorsement or promotion, the fact that some or many legislators expect or hope that many citizens will in fact use the forum as the legislators would have wished should not in itself render the forumcreating law invalid. ${ }^{36}$ Where a statute creates an open and undesignated time for personal reflection, government itself has not undertaken comparatively to favor or disfavor religion.

I am thus persuaded that there is a substantial constitutional basis for the Supreme Court's suggestion that it will sustain most statutes providing for a simple moment of silence ${ }^{37}$ while continuing to invalidate those spe-

\section{(1982).}

35. I find the argument that some neutral moment of silence statutes promote religion because they are sponsored by the same people who previously supported oral prayer statutes (or silence statutes specifically designating prayer) to be unpersuasive. What these legislatures have in fact done is to move from a statutory framework under which prayer was established or explicitly suggested by the government to one in which any prayer that occurs will be a product of private citizen choice. That, in my view, is a constitutionally critical difference.

36. One plausible piece of "legislative history" that could provide a basis for sustaining a state statute creating a neutral moment of silence would be a statement by the sponsoring State Representative to the effect:

The bill I have introduced provides simply that there will be one minute of silence at the beginning of each school day. I would not bother to bring this bill forward if I did not have some idea about how I would like to see that time used. Quite frankly, my personal goal is that I want my children to have an opportunity for a silent prayer each day, and I will, as a parent, encourage them to use the time for that purpose. You, however, may want your children to reflect upon the evils of racism or sexism, or the need for a more humane society. This legislation does not in any way suggest or favor any of these alternatives over the others. It merely creates an opportunity for personal reflection.

While I would not think it accurate to say that this legislator had a "secular purpose," neither would I say of this statute that its purpose was the "advancement or inhibition of religion," or that it was designed comparatively to favor or disfavor religion.

37. It is possible, of course, that any particular moment of silence might be implemented by local officials in a manner that impermissibly promoted religion generally or a particular religion. For 
cifically designating prayer. The Supreme Court has in fact consistently reached sound results in cases involving religion in the public schools and state universities, and is unlikely to arrive at results in this area that conflict with common sense. And here common sense would seem to indicate that a moment of reflective silence does not ordinarily constitute a legislative endorsement of religion, while the creation of a moment of silence "for prayer" does constitute such an endorsement.

II.

Whether or not a neutral moment for reflective silence is theoretically sound constitutional doctrine, the fact remains that the Supreme Court is likely to sustain such statutes. Anyone who can count to five should conclude, as Justice White did, that "a majority of the Court would approve statutes that provided for a moment of silence but did not mention prayer."38 If the proposed amendment is to have any operative effect, therefore, it must do more than merely permit the setting aside of a moment of silence. And it does: It would permit government authorities at all levels to engage in the active promotion of religious exercises. This would be a substantial change in our constitutional fabric, but it is one that the Senate Report obscures and nowhere defends.

By asserting that the amendment is "intended to reverse the effects of Jaffree $v$. Wallace as it relates to silent prayer," ${ }^{, 39}$ and by erroneously stating that the Supreme Court had "effectively outlawed" silent prayer, ${ }^{40}$ the Senate Report seems to suggest that the modest effect of adopting this amendment would be no greater than a judicial decision that permitted a state to set aside one minute for "silent prayer or meditation." Only obliquely does the Report acknowledge that the real thrust of the amendment would be to permit state sponsorship of a religious practice; such acknowledgments are accompanied by assertions of limits on state promotion that are simply inconsistent with the proposed amendment's text.11

school officials or teachers to urge that an undesignated moment of silence be used for prayer would, of course, be constitutionally invalid. There are so many ways in which government officials might promote particular religious practices that it is not possible to specify in advance all those that might be constitutionally offensive. This is in itself an argument for rejecting the blunderbuss approach of a constitutional amendment that would wholly withdraw the subject from judicial scrutiny, and an argument for retaining case-by-case adjudication.

38. Jaffree, 105 S. Ct. at 2508 (White, J., dissenting).

39. SENATE REPORT, supra note 1 , at 27.

40. Id. at 36 .

41. See id. at 29:

[I]t is intended that the Government be authorized to sponsor such prayer or reflection, to the extent of permitting the classroom teacher or other school administrator to structure the opportunity for prayer by formally announcing the period for silent prayer or reflection, ensuring discipline during the period for prayer, and formally concluding the period for prayer.

These suggested "limits" on state promotion of the exercises are wholly unrealistic and understated, as 
The critical fact that the defenders of the amendment obscure is this: Adoption of a constitutional amendment that states "[n]othing in this Constitution shall be construed to prohibit [a certain practice]" creates something like a constitutional black hole. Once constitutional limits are removed in this blanket fashion, extreme as well as moderate government actions in furtherance of the practice will be left to the vagaries of future political processes. The potential effects of this proposed amendment to the Constitution are perhaps best illustrated by the following hypothetical question: If this amendment were proposed by Congress and ratified by the States, would there remain anything in the Constitution that would prevent the U.S. Department of Education from issuing the following Federal Prayer Regulation binding on each of the 38,000 local school districts in the United States that receive federal funds?

Regulation Z-U.S. Department of Education:

Effective September 1, 2000, all school districts must, as a condition of eligibility for federal funds, comply with this regulation. Each school district shall require that ten (10) minutes be set aside at least six (6) times during each school day for silent prayer exercises. All pupils must be assembled in a common place for these prayer exercises. Use of prayer cards and rosary beads shall be permitted. (Nonconforming pupils may be released from these exercises by a timely annual filing of Form Z-1). The Superintendent of Schools, the School Board, and every principal, teacher and counselor (except for those excused on grounds of conscientious objection by annual filing of Form Z-2) shall regularly urge every pupil to participate in these silent prayer exercises through public address announcements and individual counseling. Continued eligibility for federal funding shall be dependent upon a school system having an affirmative program to encourage every child to participate in the silent prayer exercises. School districts shall file compliance forms with the Undersecretary for Prayer at the beginning of each school year.

I do not mean to suggest that such a regulation is (in the present) politically likely. ${ }^{42}$ The proposed amendment-which would be the first amendment of the First Amendment in its nearly 200-year-old history-could, however, be a part of a constitutional structure that may endure for another two centuries. We should therefore attend to its potential consequences regardless of time-bound notions of plausibility. I believe that I can defend the proposition that after adoption of this proposed amendment, Regulation $Z$ (and similar, but less radical, federal regulations) would be constitutional.

$I$ attempt to show below. See infra text accompanying notes 42-51.

42. But see Margaret Atwood's new novel, M. Atwood, The Handmaid's Tale (1985). 
The amendment begins with the provision that "[n]othing in this Constitution shall be construed to prohibit individual or group silent prayer or reflection in public schools." The expectation of the proponents of the amendment may be that state and local governments would elect to create only one-minute periods once a day to take place in the classroom where students were already seated. But once the subject of silent prayer is liberated from constitutional constraint, officials may in the course of time decide that ten minutes six times a day is more appropriate. Neither the term "moment" nor any other time limit appears in the proposed amendment. And what would stand in the way of assembling the entire student body in daily convocation for "silent prayer"? The amendment specifically immunizes "group" silent prayer from constitutional review, without limiting the size of the "group."

It will not avail to object that the hypothetical regulation would be invalid because it requires local school districts to actively promote religion. While under present constitutional law such active promotion of religion would be invalid, it is precisely this principle that, as applied to group silent prayer, the proposed amendment is designed to overturn. According to the Senate Report the purpose of the amendment is to restore "the original understanding of the 'establishment clause."'3 The supposed "original understanding" to which the Committee seeks to return is the understanding that the Constitution only precludes government promotion of particular sects, while permitting "congressional support for religion in general." 44

At another point the Senate Report states that the amendment's purpose is "to restore the historic meaning of the first amendment [which has been] sharply altered by the Court's decision in Jaffree." 45 Since the very basis of the Jaffree decision is that governments may not go beyond the creation of a moment of silence and affirmatively engage in the endorsement and promotion of religion (as the Alabama legislature had done), the only sensible reading of this passage is that government action promoting religion (at least with respect to silent prayer exercises) will be immune from constitutional scrutiny after the adoption of the amendment. ${ }^{48}$

43. SENA'TE REPORT, supra note 1 , at 2.

44. Id. at 4.

45. Id. at 2 .

46. The Senate Report confidently asserts as a fact the proposition that the establishment clause ("Congress shall make no law respecting an establishment of religion") was only "intended" to preclude the creation of a national church or governmental preference for one particular sect, and that the First $A$ mendment left the government free to promote, aid, and advance religion generally. Id. at 4 . There is, to say the least, considerable dispute about the validity of this assertion. For a recent argument that the the establishment clause precluded governmental promotion of religion generally, see L. LEVY, The Original Meaning of the Establishment Clause, in Constitutional OPINIONS: ASPECTS OF THE: BIL.I. OF Righrs 135 (1986). 
Either this amendment permits governments to promote group silent prayer exercises, or it does nothing at all. If it permits government endorsement and promotion, it permits it without any apparent limit, other than that stated in the second sentence: "Neither the United States nor any State shall require any person to participate in such prayer or reflection, nor shall they encourage any particular form of silent prayer or reflection." This is less of a qualification than might at first appear. Note that the amendment forbids only the encouragement of "any particular form" of silent prayer, thereby leaving government free to "encourage" silent prayer generally. It forbids government from "requiring" students to participate; it does not forbid government from encouraging students to participate. In short, government officials at every level would be free to promote participation by students-to suggest, counsel, and urge participation-as long as they stopped short of compulsion.

The Senate Report shows remarkably little sensitivity to the potential effects of the amendment. In one sanguine passage the Report states that "[a] reasonable effort should be made to minimize any inconvenience or embarrassment caused the nonparticipating student, and to minimize the conspicuousness with which his nonparticipation is accommodated."47 The operative word here is "should." After ratification of the amendment such sensitivity would be wholly a matter of grace with each set of government officials. Even more striking is the Report's next sentence: "No inquiries into the reason for such nonparticipation would be permitted."48 This statement is just flatly inconsistent with the text of the amendment. The amendment prevents officials only from "requiring" participation. It does not prevent officials from inquiring of students why they have chosen not to participate or from suggesting, urging, or counseling them to see the error of their ways and join group gatherings officially designated as silent prayer meetings. As long as officials refrain from "encouraging any particular form of silent prayer" they are free to encourage silent prayer generally. The Report also errs in assuming that the decision "[w]hether or not to structure a devotional exercise consistent with this amendment would be a decision in the sole discretion of those State and local authorities who are otherwise responsible for determining and administering public school policies." ${ }^{\prime \prime}$ The amendment would remove, for group silent

\footnotetext{
The notion that government may promote "religion generally" but not any particular religion is an almost incoherent concept. In the real world, any actions by government officials purportedly designed to promote "religion generally" will almost inevitably benefit some religions more than others. When the government establishes public group prayers, for example, it favors those religions for whom collective prayer is a tradition over those that prefer more private and individualized prayer.

47. SENATE REPORT, supra note 1 , at 30.

48. Id.

49. Id, at 27.
} 
prayer, the constitutional barrier of the First Amendment that presently precludes the federal government from promoting religious exercises. ${ }^{50}$ Whatever decisions state and local authorities made concerning group silent prayer exercises could simply be overridden by the federal government under the spending power. ${ }^{.1}$

In short, while the amendment is not necessary to permit states to establish a moment of silence, it (1) would permit state and local officials to take whatever steps they desired (short of compulsion) to persuade pupils to participate in silent prayer, and (2) would remove the present First Amendment barrier that precludes federal government officials from taking steps to persuade children to engage in silent prayer exercises, or from imposing federal silent prayer guidelines on state and local school systems.

I would not advance these objections so strongly if I believed that they resulted only from minor problems of drafting. These and similar problems are, on the contrary, embedded in the structure of any amendment seeking to overturn either Engle or Jaffree, for the heart of those decisions is that government itself may not sponsor, promote, or endorse religious exercises. Once government promotion is deemed acceptable, the amendment provides no stopping point that would limit the zeal which federal, state, and local governments may bring to the task. ${ }^{62}$

III.

Casting a shadow over the specific issues I have raised above is the more general question of how this Silent Prayer Amendment would be brought into harmony with the existing religion clauses of the First Amendment. Even though this amendment deals specifically only with silent prayer exercises, its underlying theory is that it is permissible for

50. The argument that federal legislative authority could be invoked was first made in testimony in opposition to President Reagan's proposed amendment by my colleague William Van Alstyne. See 1982 Hearings, supra note 4, at 466-68 (prepared statement of Professor Van Alstyne); see also Van Alstyne \& Dellinger, Government Control of Religion?, Wash. Post, Nov. 7, 1982, at B5, col. 1.

51. Anyone who doubts that after adoption of this amendment the federal government would have legislative jurisdiction to provide nation-wide guidelines requiring local school districts to hold and actively promote group silent prayer convocations should take a look at the Equal Access $\mathrm{Act}, 20$ U.S.C. $\$ 4071$ (Supp. II 1984). It provides that it shall be unlawful for any public secondary school which receives federal financial assistance to deny, under described circumstances, equal access for religious speech. Id. $\$ 4071$ (a). Once the barrier to government-promoted silent prayer exercises had been removed, Congress could use the spending power in precisely this way to impose whatever guidelines it wished on the practice of group silent prayer.

52. This is not a flaw that is likely to be cured by revision of the amendment. One could imagine adding to the amendment a list of specific steps that would constitute the exclusive means that government officials could use to endorse and promote silent prayer exercises. Such a revision, by giving prominent visibility to the fact that the amendment permits government endorsement and promotion of religion, would likely spell political doom for the amendment. If all government endorsement and promotion were forbidden, then, as I have argued above, the amendment would become a pointless recapitulation of existing law. 
government to engage in the business of promoting religion. How are the courts to reconcile the dissonance created by this principle and the contrary view that has emerged through interpretations of the establishment clause? How can one justify a jurisprudence predicated upon the notion that the Constitution (through the First Amendment) precludes governmental promotion of religion when another part of the same Constitution-the Silent Prayer Amendment-would endorse governmental promotion for one kind of religious activity? Would "silent prayer" remain an exceptional case? Or would adoption of this amendment be more properly viewed as rejection of the larger principle that forms the core of the present establishment clause? If the latter is the case, then adoption of this amendment could ultimately undercut the force of the establishment clause across the entire spectrum of government-sponsored religious activities, and not simply with respect to silent prayer exercises. This is a basic issue of constitutionalism that extends well beyond the immediate area of prayer and religion. The awkwardness and uncertainty of reconciling the specific with the general counsels strongly, in my view, against placing in the Constitution any provision (other than one dealing with organizational matters, such as the term of the President) that does not establish a constitutional principle, but deals instead with one very specific practice.

\section{IV.}

It is, of course, possible that I am mistaken that this amendment would permit active, intrusive governmental promotion of silent prayer exercises. It is possible that the amendment would be tightly and strictly construed. If it were interpreted to permit only the setting aside of an undesignated moment of silence, it is simply unnecessary. If it goes one step further and permits legislators to designate such a moment as being "for prayer" while somehow precluding any additional promotional activities, it would change in that one respect what seems to be the evolving law. It would, in that case, constitute the most trivial amendment to the Constitution of the United States ever proposed by Congress.

Even if the amendment is so trivial that its incorporation into the Constitution would do no lasting harm to the fabric of religious freedom, its submission to the states could nonetheless be a thoughtlessly harmful act. Proposal by the Congress of an amendment to the Constitution launches an uncertain process. ${ }^{53}$ There is much that we do not know about the law of constitutional amendment. We have no definitive answer to questions as basic as whether a state may rescind an earlier ratification, or whether

53. On the present uncertainty of the amendment process, see Dellinger, The Legitimacy of Constitutional Change: Rethinking the Amendment Process, 97 HARv. L. Rev. 386 (1983). 
Congress can extend a time deadline for ratification. What the Senate Judiciary Committee proposes to do is to send out to fifty state capitols a potentially divisive amendment that is likely to heighten religious tensions in this country. From Montpelier to Sacramento, from Tallahassee to Juneau, we are likely to witness ratification debates that set Jew against Gentile, and that place the Knights of Columbus in conflict with the United Presbyterian Church. For seven (perhaps ten) years, we may witness a struggle among religious groups over whether to ratify this apparently trivial but potentially dangerous amendment to the Constitution.

I urge you and your colleagues to refrain from submitting this unwise and unnecessary amendment to the states.

Respectfully,

Walter Dellinger /s/

Professor of Law

Duke University 